\title{
Epiphytic Bacteria from Sweet Pepper Antagonistic In Vitro to Ralstonia solanacearum BD 261, a Causative Agent of Bacterial Wilt
}

\author{
Tshifhiwa Paris Mamphogoro ${ }^{1,2} \mathbb{D}^{-}$, Casper Nyaradzai Kamutando $\left.{ }^{3}{ }^{(}\right)$, Martin Makgose Maboko ${ }^{4}\left({ }^{\circ}\right.$, \\ Olayinka Ayobami Aiyegoro $1,5, *$ (i) and Olubukola Oluranti Babalola ${ }^{2}$ (])
}

check for

updates

Citation: Mamphogoro, T.P.; Kamutando, C.N.; Maboko, M.M.; Aiyegoro, O.A.; Babalola, O.O. Epiphytic Bacteria from Sweet Pepper Antagonistic In Vitro to Ralstonia solanacearum BD 261, a Causative Agent of Bacterial Wilt. Microorganisms 2021, 9, 1947. https: //doi.org/10.3390/microorganisms 9091947

Academic Editor: Charles M. Dozois

Received: 29 July 2021

Accepted: 25 August 2021

Published: 14 September 2021

Publisher's Note: MDPI stays neutral with regard to jurisdictional claims in published maps and institutional affiliations.

Copyright: (C) 2021 by the authors Licensee MDPI, Basel, Switzerland. This article is an open access article distributed under the terms and conditions of the Creative Commons Attribution (CC BY) license (https:/ / creativecommons.org/licenses/by/ $4.0 /)$.
1 Gastro-Intestinal Microbiology and Biotechnology Unit, Agriculture Research Council-Animal Production, Private Bag X02, Irene, Pretoria 0062, South Africa; MamphogoroT@arc.agric.za

2 Food Security and Safety Niche Area, Faculty of Natural and Agricultural Sciences, North-West University, Private Bag X2046, Mmabatho 2735, South Africa; olubukola.babalola@nwu.ac.za

3 Department of Plant Production Sciences and Technologies, University of Zimbabwe, P.O. Box MP167, Mount Pleasant, Harare 0263, Zimbabwe; kamutandocn@gmail.com

4 Crop Science Unit, Agriculture Research Council-Vegetable and Ornamental Plants, Private Bag X293, Roodeplaat, Pretoria 0001, South Africa; mmaboko@yahoo.com

5 Research Unit for Environmental Sciences and Management, North-West University, Private Bag X1290, Potchefstroom 2520, South Africa

* Correspondence: ayoyinkaaiyegoro@gmail.com

\begin{abstract}
Biological control of plant pathogens, particularly using microbial antagonists, is posited as the most effective, environmentally-safe, and sustainable strategy to manage plant diseases. However, the roles of antagonists in controlling bacterial wilt, a disease caused by the most devastating and widely distributed pathogen of sweet peppers (i.e., R. solanacearum), are poorly understood. Here, amplicon sequencing and several microbial function assays were used to depict the identities and the potential antagonistic functions of bacteria isolated from 80 red and green sweet pepper fruit samples, grown under hydroponic and open soil conditions, with some plants, fungicide-treated while others were untreated. Amplicon sequencing revealed the following bacterial strains: Bacillus cereus strain HRT7.7, Enterobacter hormaechei strain SRU4.4, Paenibacillus polymyxa strain SRT9.1, and Serratia marcescens strain SGT5.3, as potential antagonists of $R$. solanacearum. Optimization studies with different carbon and nitrogen sources revealed that maximum inhibition of the pathogen was produced at $3 \%(w / v)$ starch and $2,5 \%(w / v)$ tryptone at $\mathrm{pH} 7$ and $30{ }^{\circ} \mathrm{C}$. The mode of action exhibited by the antagonistic isolates includes the production of lytic enzymes (i.e., cellulase and protease enzymes) and siderophores, as well as solubilization of phosphate. Overall, the results demonstrated that the maximum antimicrobial activity of bacterial antagonists could only be achieved under specific environmental conditions (e.g., available carbon and nitrogen sources, $\mathrm{pH}$, and temperature levels), and that bacterial antagonists can also indirectly promote crop growth and development through nutrient cycling and siderophore production.
\end{abstract}

Keywords: antagonists; biological control; epiphytes; sweet pepper; $16 \mathrm{~S}$ rRNA genes; Ralstonia solanacearum

\section{Introduction}

Sweet pepper (Capsicum annum), a heat-loving vegetable species, is grown worldwide, with an estimated fruit yield of more than 32.3 million tonnes, annually [1]. In a world were some communities or households can be food secure, but nutritionally insecure [2,3], peppers can bridge this gap, as they harbor important nutritional attributes. For example, risks of human disease such as cancer, heart disease, and diabetes were reported to be minimized by polyphenols and flavonoids [4,5], which are biochemicals highly concentrated in peppers [6-8]. Pepper fruits are usually used for spicing because of their flavour [9]. Due to 
these reasons, demand for sweet pepper fruits may increase, and this calls for intervention measures that can promote the productivity of this important crop on a global scale.

Yield and fruit quality of sweet peppers were previously reported to be influenced by genotype [10] as well as the farming system (i.e., agronomic management) [11]. Both, the crop genotype and crop management practices are traditionally known to affect yield development and crop quality, but this happens in an environment endowed with abiotic and biotic stress factors. For example, under disease stress, some plants may tolerate or resist infections genetically, either through physiological or biochemical mechanisms [12,13]. In order to withstand disease pressures, the plant genotype was also reported as instrumental in shaping the surrounding microbial communities, to harbour mostly those microbial taxa with plant growth-promoting potentials, including antagonists of the pathogenic taxa $[14,15]$.

The top ten, most problematic bacterial pathogens of crops were previously listed, with Pseudomonas syringe pathovars and Ralstonia solanacearum topping the list [16]. In sweet peppers, $R$. solanacearum is regarded as the most damaging and yield constraining pathogen $[17,18]$. R. solanacearum causes a disease known as bacterial wilt. Apart from peppers, this pathogen also attacks over 200 other plant species and it is distributed worldwide, where it was observed to induce a destructive economic impact [19]. Affected plants usually show rapid and fatal wilting symptoms [20]. Over the years, farmers have struggled to control this pathogen, because of its ability to grow endophytically, survive in deep soil horizons, and migrate in water, and its ability to associate with weeds [21]. Therefore, more pragmatic approaches to control this pathogen, especially those measures that are sustainable and environmentally friendly, need to be developed.

Biological control agents (especially, antagonists) are widely accepted as sustainable and ideal for protecting the integrity of ecosystems and biodiversity [22-24]. For instance, field evaluations of the bacterial antagonists Bacillus amyloliquefaciens SQR-7 and SQR-101 and B. methylotrophicus SQR-29 against $R$. solanacearum showed biocontrol efficacy (BE) of $18-60 \%$ in tobacco [25]. Elsewhere, the antagonist Ralstonia pickettii QL-A6 indicated a BE of $73 \%$ against $R$. solanacearum in tomato plants [26]. B. stratosphericus strain LT743897 proved to increase secondary metabolite production in S. lycopersicum plants, resulting in growth promotion and in vivo antagonistic activity. The strain also stimulated the SA defense mechanism against $R$. solanacearum infecting pathogens [27]. In our recent study, 16S rRNA amplicon sequencing data of samples collected from surfaces of red and green sweet pepper fruits, grown under hydroponic (fungicide treated + untreated) and open soil (fungicide treated + untreated) systems, revealed several bacterial taxa with the potential to antagonize pathogenic microorganisms [28]. However, details on the antagonists that can suppress the most important pathogens of sweet peppers, such as $R$. solanacearum, are not yet available.

Therefore, this study aimed to isolate, characterize, and evaluate potential bacterial antagonists, residing on the surfaces of red and green sweet pepper fruits, sampled from plants grown under different management conditions (i.e., hydroponic and open soil conditions, but either fungicide-treated or untreated) for their ability to suppress $R$. solanacearum BD 261. We hypothesized that sweet pepper fruits harbor some specific bacterial strains on their surfaces that inhibit the proliferation of pathogenic strains such as $R$. solanacearum $\mathrm{BD}$ 261 , and that these antagonists are more important on plants grown in open soil, where disease pressures are typically high.

\section{Materials and Methods}

\subsection{Study Sites and Crop Management}

Sweet peppers (cv. King Arthur) were planted in October 2014 and were maintained until March 2015, at the Agricultural Research Council-Vegetable and Ornamental Plants Institute (ARC-VOP), in Roodeplaat, Pretoria, South Africa (Latitude $=1200$, Longitude $=25^{\circ} 59^{\prime} \mathrm{S} ; 28^{\circ} 35^{\prime} \mathrm{E}$ ). Plants were grown in a hydroponic system as well as under open field conditions. The mean temperature under hydroponic growing conditions was 
$33{ }^{\circ} \mathrm{C}$ day $/ 15^{\circ} \mathrm{C}$ night. In the open field, average temperatures of $34.5^{\circ} \mathrm{C}$ day $/ 15^{\circ} \mathrm{C}$ night were recorded. The experimental design was a 2 (treatments, i.e., fungicide-treated (T) and untreated $(\mathrm{U})) \times 2$ (growing conditions, i.e., hydroponic $(\mathrm{H})$ and open field $(\mathrm{S})) \times 2$ (maturity stages, i.e., green $(\mathrm{G})$ and red $(\mathrm{R})$ colour) factorial, with ten replicates, thereby making-up a total of 80 planting stations.

Cultivation practices of sweet pepper for the field and hydroponic growing conditions were previously reported in detail by [28]. Two weeks after transplanting (WAT), plants were treated with Copper-count (5 mL/L) Hygrotech (Pty) Ltd., Pretoria, South Africa), Sporekill (1 mL/L) (ICA International Chemicals (Pty) Ltd., Stellenbosch, South Africa), Binomyl (50 g/L) (Villa Crop Protection (Pty) Ltd., Kempton Park, South Africa), Bravo $(210 \mathrm{~mL} / \mathrm{L})$ and Ridomol gold $(360 \mathrm{~mL} / \mathrm{L})$ (Syngenta, Centurion, South Africa), to control against powdery mildew, blight, and leaf spot. Insecticides such as Actar $(50 \mathrm{~mL} / \mathrm{L})$ (Syngenta, Centurion, South Africa), Hunter (40 mL/L) (BASF Pty Ltd., Midrand, South Africa), Diozinon (160 mL/L) (AVIMA (Pty) Ltd., Kenmare, South Africa), Biomectine $(60 \mathrm{~mL} / \mathrm{L})$ (Villa Crop Protection (Pty) Ltd., Kempton Park, South Africa), and Savage (40 mL/L) (Villa Crop Protection (Pty) Ltd., Kempton Park, South Africa), were also applied to control white flies, red spider mites, and aphids.

\subsection{Sample Collection, Processing, and Isolation of Potential Antagonists}

A total of 80 (i.e., $10 \mathrm{HGT}+10 \mathrm{HRT}+10 \mathrm{HGU}+10 \mathrm{HRU}+10 \mathrm{SGT}+10 \mathrm{SRT}+10 \mathrm{SGU}$ + 10 SRU), fresh, intact, and health green and red sweet pepper fruits were aseptically collected in sterile Ziploc bags and kept at $4{ }^{\circ} \mathrm{C}$ in the lab. Bacterial biofilms on the surfaces of the pepper fruits were recovered using sterile cotton swabs soaked in a solution containing $0.15 \mathrm{M} \mathrm{NaCl}$ and $0.1 \%$ Tween 20, as in [29]. The swabs were vortexed in sterile Eppendorf tubes containing saline solution $(0.85 \% \mathrm{NaCl})$. The supernatant was serially diluted and one hundred $\mu \mathrm{L}$ aliquots from the $10^{-1}$ and $10^{-2}$ dilutions were plated on Trypticase soy agar (TSA). The plates were incubated for $48 \mathrm{~h}$ at $30{ }^{\circ} \mathrm{C}$ under aerobic conditions. Ten colonies per plate with unique morphologies were selected based on differences in colour, shape, and texture, for further purification (i.e., $\mathrm{n}=800,80$ swabs $\times 10$ colonies; Table S1). Purified colonies were streaked on TSA and incubated at $37{ }^{\circ} \mathrm{C}$ for $24 \mathrm{~h}$, and stored on a Trypticase soy broth (TSB) medium containing $50 \%$ glycerol at $-80{ }^{\circ} \mathrm{C}$ for further use.

\subsection{Plant Bacterial Pathogen}

The plant pathogenic bacteria R. solanacearum BD 261 (Phylotype II race 3 biovar 2) [30], isolated from wilted tomato plants and was acquired from the culture bank of the ARC's Plant Protection Biosystems Laboratories, in Pretoria, South Africa (www.arc.agric.za/arc-ppri). The pathogen was maintained on 2-3-5 triphenyl tetrazolium chloride (TZC) in McCartney bottles at $4{ }^{\circ} \mathrm{C}$ until use. Stock cultures of the test pathogen were prepared for use throughout the study and maintained in the culture collection of the ARC's Gastro Intestinal Microbiology and Biotechnology Laboratories, which are under the Animal Production Institute, Irene (www.arc.agric.za/arc-api).

\subsection{Multiplication of Potential Antagonists and the Pathogen}

Multiplication of potential antagonists and pathogens followed procedures in [31], but with minor modifications. Isolates were grown on TSA medium and pathogens from TZC medium were re-cultured on sucrose peptone broth (SPB) medium containing $\left(\mathrm{gL}^{-1}\right)$; sucrose (20), peptone (5), $\mathrm{K}_{2} \mathrm{HPO}_{4}(0.5), \mathrm{MgSO}_{4} .7 \mathrm{H}_{2} \mathrm{O}(0.25)$, and $\mathrm{pH}$ 7.2-7.4. The growth of potential antagonists and $R$. solanacearum BD 261 isolates was performed at $30{ }^{\circ} \mathrm{C}$ with shaking for $48 \mathrm{~h}$ [32].

\subsection{In Vitro Screening of Isolates for Antagonism}

Antibacterial activity screening of potential antagonists against $R$. solanacearum BD 261 was conducted before and after enrichment using an optimized spot-on-lawn assay [33]. Briefly, $200 \mu \mathrm{L}$ of $R$. solanacearum BD 261 cell culture $\left(\mathrm{OD}_{600} \sim 0.4\right)$ was grown in SPB 
medium and then grown on cooled King's $\mathrm{B}$ agar medium plates which contained $\left(\mathrm{gL}^{-1}\right)$; protease peptone (20), $\mathrm{MgSO}_{4} .7 \mathrm{H}_{2} \mathrm{O}(1.5), \mathrm{K}_{2} \mathrm{HPO}_{4}$ (1.5), glycerol (10 mL), and agar (15), at $\mathrm{pH}$ 7.2. Plates were dried for $40-50 \mathrm{~min}$, and five wells ( $5 \mathrm{~mm}$ in diameter) were made per plate using a cork borer, with $50 \mu \mathrm{L}$ of each potential bacterial antagonist grown in SPB (i.e., $\mathrm{OD}_{600} \sim 0.4$ ) was added into each well. Fifty (50) $\mu \mathrm{L}$ of cell culture of Bacillus stratosphericus $\mathrm{LT743897}\left(\mathrm{OD}_{600} \sim 0.4\right)$ grown in SPB was used as a positive control. The inhibition zone of the bacterial isolates on $R$. solanacearum strain BD 261 was measured after $48 \mathrm{~h}$ of incubation at $30^{\circ} \mathrm{C}$. The experiments were performed at least three times.

\subsection{DNA Extraction and PCR Amplification of Potential Antagonistic Strains 2.6.1. PCR Amplification of $16 \mathrm{~S}$ rRNA Genes}

Total genomic DNA of potential antagonistic strains was extracted from pure cultures using the Quick-DNA Fungal/Bacterial Miniprep Kit Zymo Research D6005 according to the manufacturer's instructions (www.zymoresearch.com). In general, one $\mu \mathrm{L}$ of genomic DNA was used as a template to amplify the full-length of the 16S rRNA gene [34]. An approximately $1.5 \mathrm{~kb}$ fragment part of the $16 \mathrm{~S}$ rRNA gene was amplified using the universal primer pair (27F:5'-AGAGTTTGATCCTGGCTCAG-3' and 1492R:5'GGTTACCTTGTTACGACTT- ${ }^{\prime}$ ) [35]. Amplifications were performed in 20- $\mu$ L reaction volumes containing, $10 \mu \mathrm{L}$ One Taq $2 X$ Master Mix with Standard Buffer (NEB, catalogue No. M048S, Invitrogen, Carlsbad, CA, USA; 1X), $1 \mu \mathrm{L}$ of both primers: 27F and 1492R with a concentration of $10 \mu \mathrm{M}, 7 \mu \mathrm{L}$ Nuclease free water (Catalogue No. E476), and $1 \mu \mathrm{L}$ DNA template $(10-30 \mathrm{ng} / \mu \mathrm{L})$.

PCR was performed using Thermal Cycler (MJ Mini Personal Thermal Cycler, Bio-Rad; www.bio-rad.com). The PCR conditions were as follows: initial denaturation at $94{ }^{\circ} \mathrm{C}$ for $3 \mathrm{~min}$, followed by 30 cycles of $94^{\circ} \mathrm{C}$ for $30 \mathrm{~s}, 50{ }^{\circ} \mathrm{C}$ for $30 \mathrm{~s}, 68^{\circ} \mathrm{C}$ for $1: 30 \mathrm{~min}$, and then a final elongation step at $68{ }^{\circ} \mathrm{C}$ for $5 \mathrm{~min}$. The amplified genes were ran on $1 \%$ agarose gel electrophoresis CSL-AG500 (Cleaver Scientific Ltd.; www.cleverscientific.com), stained with EZ-vision Bluelight DNA Dye with the size markers (10 kb Fast DNA ladder NEB N3238, Invitrogen, Forster city, CA, USA; www.amresco-inc.com) and then cleaned with ExoSAP, a mixture of Exonuclease I NEB M0293L and Shrimp Alkaline Phosphatase NEB M0371 (Invitrogen, Waltham, MA, USA).

\subsubsection{Sequencing and Bioinformatics Analysis of the $16 \mathrm{~S}$ rRNA Amplicons}

The cleaned amplicons were sequenced at Inqaba Biotechnical Industries (Pty) Limited (www.inqababiotec.co.za) in the forward and reverse direction, using the Nimagen, BrilliantDye $^{\mathrm{TM}}$ Terminator Cycle Sequencing Kit V3.1, BRD3 100/1000, Nijmegen, Netherlands, following the manufacturer's instructions. Amplicons were then purified with the Zymo Research, ZR-96 DNA Sequencing Clean-up Kit D4053, Irvine, CA, USA. Purified fragments were analyzed on the ABI 3500XL Genetic Analyzer with a 50-cm array, using POP7 (Applied Biosystems, ThermoFisher Scientific., Foster City, CA, USA) for each reaction for every sample. The sequence chromatogram generated by the ABI 3500XL Genetic Analyzer were analysed using the FinchT v1.4 software, and the obtained results were compared with the related 16S-rDNA sequences identified by the Basic Local Alignment Search (BLAST) search program on the National Center for Biotechnology Information (NCBI), National Library of Medicine, USA [36].

Sequence alignments were performed using the CLUSTLW algorithm in MEGA v6.06 [37] with default settings, and phylogenetic trees were constructed using the neighborjoining method [38]. Reliability of the phylogenetic tree was evaluated through bootstrap analysis with 1000 re-samplings using a p-distance model, with the numbers on branches indicating percentage level of bootstrap support as described in [38].

\subsubsection{Nucleotide Sequence Accession Numbers}

The nucleotide sequences of the 16S rRNA genes has been deposited in the GenBank database under accession numbers MN911398.1—MN911401.1. 


\subsection{Optimization for Improved Activity of Potential Antagonistic Strains}

The screened bacterial antagonistic strains were inoculated into SPB enriched with different compositions of carbon sources (including; fructose, glucose, lactose, maltose and starch) and nitrogen sources (i.e., ammonium sulfate, ammonium chloride glycine, yeast and tryptone) at different $\mathrm{pHs}$ (ranging from 5-9, adjusted with $1 \mathrm{~N} \mathrm{HCl}$ and $1 \mathrm{~N} \mathrm{NaOH}$ ), and incubated at $30^{\circ} \mathrm{C}$ on shaker for $48 \mathrm{~h}$ as in $[27,39]$. After incubation, the antagonistic strains were screened against plant pathogens $R$. solanacearum BD 261 on King's B agar plates using a spot-on-lawn assay at different $\mathrm{pHs}$ and observed for inhibition zones as described in [33]. The antagonists were then cultured at concentrations of $0.5,1,1.5,2,2.5$, and $3 \%(w / v)$ with optimized carbon and nitrogen sources and $\mathrm{pH}$. Potent strains displaying the highest potential for $R$. solanacearum BD 261 suppression at the highest concentration of optimized carbon, nitrogen sources, and $\mathrm{pH}$ were allowed to grow at 25, 28, 30, 35, and $37^{\circ} \mathrm{C}$ for $24-48 \mathrm{~h}$ together with $R$. solanacearum BD 261, using the perforated agar plate technique [32]. Plates were then examined for inhibition zones which were measured and recorded. The temperature exhibiting the maximum suppression of $R$. solanacearum $\mathrm{BD} 261$ was recognized as the optimum temperature for determining antagonistic effects of the pathogen for further studies. The experiments were performed at least three times.

\subsection{Determination of Potential Antimicrobial Traits}

\subsubsection{Cellulase Activity}

Cellulase activity was determined as described by [40] with minor modifications. Briefly, the supernatants of antagonistic strains $(50 \mu \mathrm{L})$ were inoculated into the wells of carboxymethyl cellulose (CMC) agar medium containing $\left(\mathrm{gL}^{-1}\right)$ : $\mathrm{KH}_{2} \mathrm{PO}_{4}(1.0), \mathrm{MgSO}_{4} \cdot 7 \mathrm{H}_{2} \mathrm{O}$ (0.5), $\mathrm{NaCl}(0.5), \mathrm{FeSO}_{4} \cdot 7 \mathrm{H}_{2} \mathrm{O}(0.01), \mathrm{MnSO}_{4} \cdot \mathrm{H}_{2} \mathrm{O}(0.01), \mathrm{NH}_{4} \mathrm{NO}_{3}(0.3), \mathrm{CMC}(10)$ and agar (15). After incubation at $25{ }^{\circ} \mathrm{C}$ for $72 \mathrm{~h}$, plates were flooded with $0.1 \%$ Congo red for $20 \mathrm{~min}$ and then with $1 \mathrm{M} \mathrm{NaCl}$ for $20 \mathrm{~min}$. Production of cellulase was identified by a zone hydrolysis formation around the colonies. The experiment was conducted in triplicate.

\subsubsection{Protease Activity}

Protease activity was determined by inoculating antagonistic strains. Supernatants $(50 \mu \mathrm{L})$ were added into wells of LB agar medium containing 3\% skim milk powder and incubated at $28^{\circ} \mathrm{C}$ for $72 \mathrm{~h}$. A clear zone around the test strains after incubation was used as an indicator for protease production [41]. The experiment was conducted in triplicate.

\subsubsection{Detection of Phosphate Solubilization}

Phosphate solubilization was carried out in a minimal medium, according to [42] with slight modification. This medium contained ( $\left.\mathrm{gL}^{-1}\right)$ : glucose (10), $\mathrm{Ca}_{3}(\mathrm{PO} 4)_{2}(5),\left(\mathrm{NH}_{4}\right)_{2} \mathrm{SO}_{4}$ (0.5), $\mathrm{NaCl}(0.2), \mathrm{MgSO}_{4} \cdot 7 \mathrm{H}_{2} \mathrm{O}(0.1), \mathrm{KCl}(0.1)$, yeast extract $(0.2), \mathrm{MnSO}_{4} \cdot \mathrm{H}_{2} \mathrm{O}(0.001)$, $\mathrm{FeSO}_{4} \cdot 7 \mathrm{H}_{2} \mathrm{O}(0.001)$ and agar (20) at $\mathrm{pH} 6.8$. After cooling the media to $50^{\circ} \mathrm{C}$, supernatants of the antagonistic strains $(50 \mu \mathrm{L})$ were added on the wells of the medium plates and incubated for $72 \mathrm{~h}$ at $25^{\circ} \mathrm{C}$. Phosphate solubilization was determined by observing a clear zone around the colonies. The experiment was conducted in triplicate.

\subsubsection{Siderophore Production}

Production of siderophores was assessed by the universal modified chemical assay using Chrome azurol S (CAS) agar medium prepared as in [43]. The CAS agar plates were used to detect for presence of siderophores in culture supernatants of the potential antagonistic strains. The CAS agar plates consist of two main components (i.e., the CAS indicator solution and the Basal agar medium). The CAS indicator solution was prepared by dissolving $60.5 \mathrm{mg}$ CAS in $50 \mathrm{~mL}$ distilled water, mixed with $10 \mathrm{~mL}$ of $\mathrm{Fe}^{+3}$ (27 mg

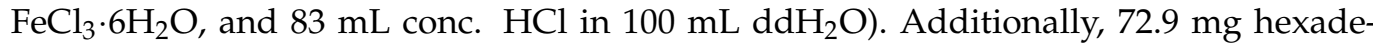
cyltrimethylammonium bromide (HDTMA) dissolved in $40 \mathrm{~mL}$ distilled water was also slowly added while stirring to give a dark blue $100 \mathrm{~mL}$ total volume. The solution was autoclaved before use. 
The Basal agar medium consisted of a mixture of $10 \mathrm{~mL}$ MM9 salt stock solution which contained $30 \mathrm{~g} \mathrm{KH}_{2} \mathrm{PO}_{4}, 50 \mathrm{~g} \mathrm{NaCl}$ and $100 \mathrm{~g} \mathrm{NH}_{4} \mathrm{Cl}$ in $1 \mathrm{~L}$ ddH $\mathrm{g}_{2} \mathrm{O}, 3.23 \mathrm{~g}$ PIPES and $12 \mathrm{~g}$ of $\mathrm{NaOH}$, all dissolved in $75 \mathrm{~mL}$ using distilled water, with $\mathrm{pH}$ adjusted to 6.8. After adjusting the $\mathrm{pH}, 1.2 \mathrm{~g}$ agar was added while stirring. The resultant solution was then autoclaved. After cooling the media to $50{ }^{\circ} \mathrm{C}, 10 \mathrm{~mL}$ blue dye solution, $3 \mathrm{~mL}$ of $10 \%$ Casamino acid solution, and $10 \mathrm{~mL}$ of $20 \%$ glucose as a carbon source were slowly added along the glass wall with adequate agitation to blend thoroughly. The potential antagonistic strains supernatants $(50 \mu \mathrm{L})$ were applied in a well on each CAS plate, and the plates were incubated at $25^{\circ} \mathrm{C}$ for $72 \mathrm{~h}$. Observation of formation of yellow-orange halos around the bacterial colonies designated siderophore production. The experiment was conducted in triplicate.

\subsection{Statistical Data Processing}

Antibacterial activity screening (i.e., inhibition zones) collected before and after enrichment and gathered data (i.e., inhibition zones) for each of the different treatment levels (i.e., $\mathrm{pH}$, carbon and nitrogen sources, temperature, etc.) was subjected, firstly, to analysis of variance (ANOVA) using the ' $a o v^{\prime}$ function in the agricolae v1.3-1 R package. Statistical differences between the isolates and the positive control in suppressing the $R$. solanacearum strain BD 261 were detected using the Tukey's HSD test, using the 'TukeyHSD' function in the agricolae R package [44]. In order to visualize how the isolates differ in performance (i.e., pathogen suppression), in comparison with the control isolate, a scatter plot was used. Scatter plots were graphed using the 'ggplot' function in the ggplot2 v3.0.0 R package [45].

\section{Results}

\subsection{Isolation and Identification of Potent Bacterial Strains}

Bacterial isolations yielded a total of 800 colonies (i.e., isolates) that showed unique morphologies in terms of colour, shape, and texture. In particular, the 800 isolates consisted of 10 colonies selected from each of the 80 sweet pepper fruit samples (i.e., 10 HGT (hydroponic green treated) + 10 HRT (hydroponic red treated) + 10 HGU (hydroponic green untreated) + $10 \mathrm{HRU}$ (hydroponic red untreated) + $10 \mathrm{SGT}$ (soil green treated) + 10 SRT (soil red treated) + 10 SGU (soil green untreated) + 10 SRU (soil red untreated)) (Table S1). Among the 800 isolated strains, only four exhibited inhibitory effects against $R$. solanacearum BD 261. These antagonistic strains were identified as HRT7.7, SGT5.3, SRT9.1, and SRU4.4 (Table S1; Figure S1).

Briefly, the isolate identified as HRT7.7 showed the highest sequence similarity with Bacillus cereus MN589698 (99\%), SRU4.4 shared the highest sequence similarity with Enterobacter hormaechei MN428803 (98\%), SRT9.1 showed close identity with Paenibacillus polymyxa MK791706 (99\%), while SGT5.3 was similar to Serratia marcescens MN155793.1 (99\%). Based on these similarities, the isolates have been coded as below: HRT7.7 as Bacillus cereus strain HRT7.7; SRT9.1 as Paenibacillus polymyxa strain SRT9.1; SGT5.3 as Serratia marcescens strain SGT5.3; and lastly, SRU4.4 as Enterobacter hormaechei strain SRU4.4 (Table 1). Phylogenetic analysis of the 16S rRNA gene sequences showed that the isolated antagonistic strains clustered with other genera of Bacillus, Enterobacter, Paenibacillus, and Serratia (Figure 1).

Assessing the antagonistic potential of the isolates, before and after enrichment, also revealed some interesting trends. Firstly, the four isolates and the control strain significantly differed $(p<0.05)$ in their ability to suppress the $R$. solanacearum BD 261 strain, both before and after enrichment (Table S2). Generally, before enrichment, all the isolates (including the control) showed low potential in inhibiting the pathogenic strain. However, the strains, SRT9.1 (Paenibacillus polymyxa strain SRT9.1) and SRU4.4 (Enterobacter hormaechei strain SRU4.4), with inhibition zones of $8.1 \mathrm{~mm}$ and $9.1 \mathrm{~mm}$, respectively, exhibited a huge potential in suppressing the pathogenic strain before enrichment. After enrichment, a jump in antagonistic potential was shown for all the isolates, together with the control (Figure 2; 
Table S3). Interestingly, the inhibitory potential of the control was significantly $(p<0.05)$ lower than all of the newly identified antagonistic strains (Table S4).

Table 1. Molecular identification of 16S rRNA gene of epiphytic bacterial strains with in vitro antagonistic traits.

\begin{tabular}{cccccc}
\hline Sample No & Strain Code $^{\mathbf{a}}$ & Base Pair Length $^{\mathbf{b}}$ & Species Name & Accession No $^{\mathbf{c}}$ & Similarity (\%) $^{\text {(\%) }}$ \\
\hline 1 & HRT7.7 & $1264 \mathrm{bp}$ & Bacillus cereus strain HRT7.7 & MN911398.1 & 99 \\
2 & SGT5.3 & $1254 \mathrm{bp}$ & Serratia marcescens strain SGT5.3 & MN911401.1 & 99 \\
3 & SRT9.1 & $1265 \mathrm{bp}$ & Paenibacillus polymyxa strain SRT9.1 & MN911399.1 & 99 \\
4 & SRU4.4 & $1255 \mathrm{bp}$ & Enterobacter hormaechei & MN911400.1 & 98 \\
\hline
\end{tabular}

${ }^{a}$ Code for the selected strains with antagonistic traits. ${ }^{b}$ Fragment length of selected strain. ${ }^{c}$ GeneBank sequence accession numbers of selected strains.

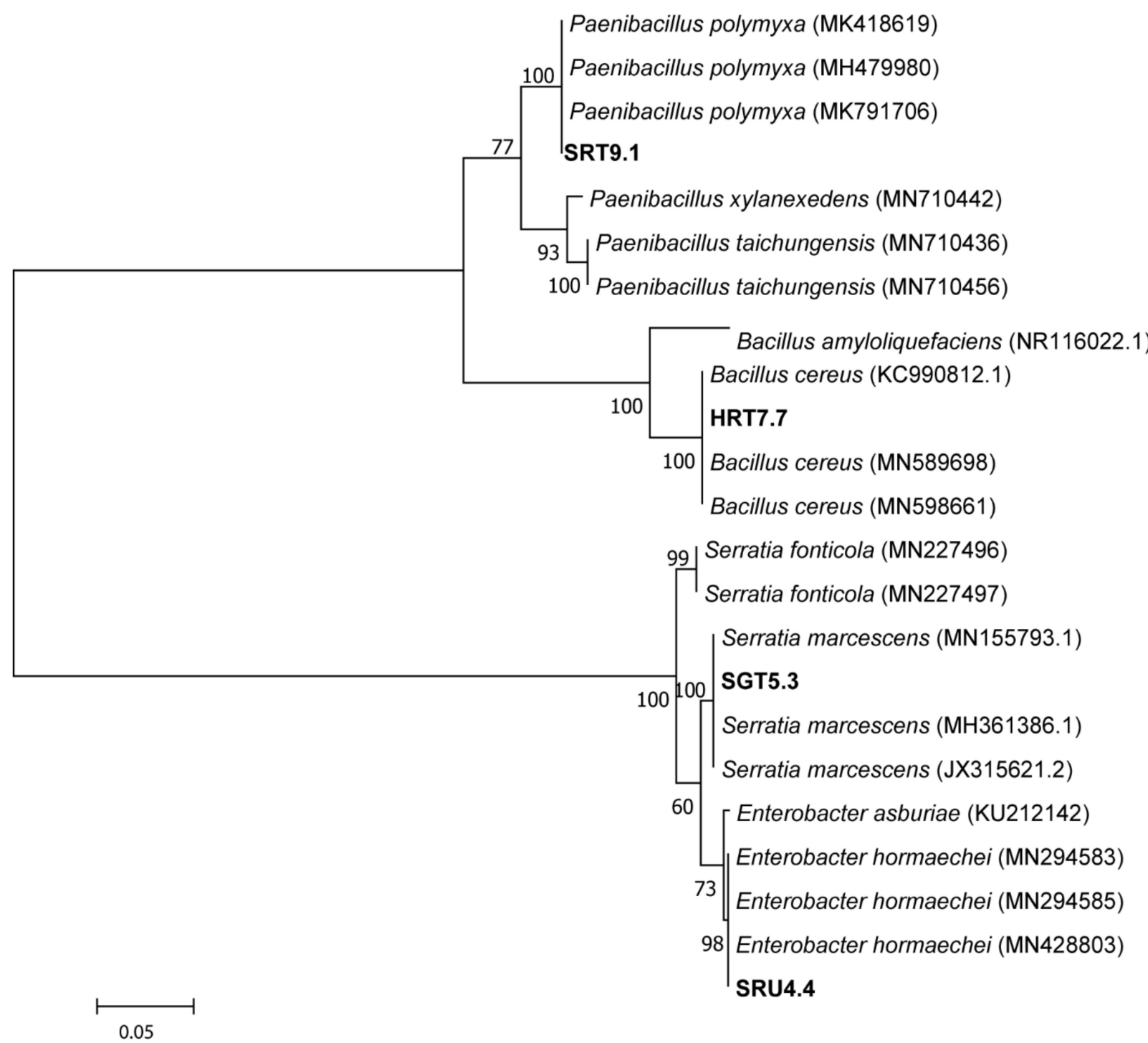

Figure 1. Neighbor-joining phylogenetic tree based on 16S rRNA gene sequences of potential antagonistic strains showing the relationship of closest type strain sequences. The phylogenetic tree was constructed using the neighbour-joining algorithm. The tree is based on 1000 resampled datasets and the numbers on branches indicate the percentage level of bootstrap support. 


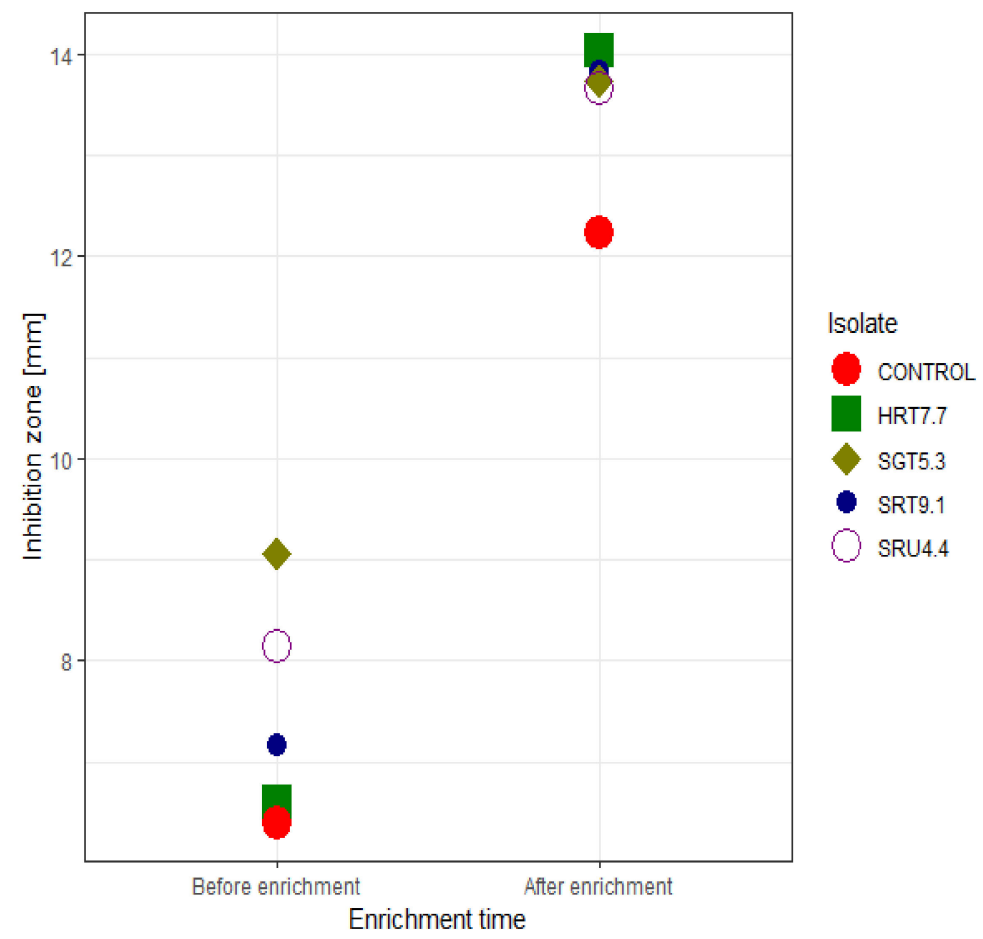

Figure 2. A scatter plot showing inhibition zones of the sweet pepper fruits isolates against the $R$. solanacearum $\mathrm{BD} 261$ pathogenic strain, before and after enrichment.

\subsection{Optimization for Enhanced Antagonistic Activity}

Determining the effects of the different treatment levels of $\mathrm{pH}$, carbon and nitrogen source, temperature, and the concentration of carbon and nitrogen source (starch and tryptone) on the antagonistic potential of the bacterial isolates from the sweet pepper fruit samples showed encouraging results. First, at these different treatment levels, the isolates differed significantly (i.e., $p<0.05$ ) in their ability to deter the function of the pathogenic strain $R$. solanacearum $\mathrm{BD} 261$ (except for $\mathrm{pH}=6$ and the yeast extract treatments; Table 2). The highest antagonistic activity was observed at a neutral $\mathrm{pH}$, but $\mathrm{pH}$ levels above 6, all seemed to enhance the inhibitory activities of the antagonistic strains, with inhibitory zones above $10 \mathrm{~mm}$, in most cases (Figure 3A; Table S5). Furthermore, the effects of the isolates at different $\mathrm{pH}$ significantly differed from the control (Table S6).

Carbon sources, including lactose, fructose, and starch, influenced the antagonistic potential of the isolates to the highest degree. Starch proved to be the ideal carbon source, with inhibition zones above $13.5 \mathrm{~mm}$ for all the isolates (Figure 3B; Table S5). Of note, all the isolates significantly differed from the control in their ability to inhibit the pathogenic strain when supplied with starch (Table S6). Additionally, the antagonists seemed to favour starch at higher concentrations for optimal activity (Figure 3D). 


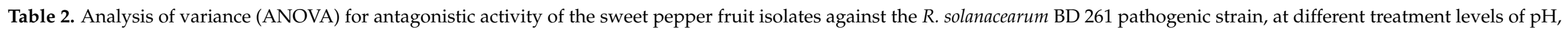
carbon sources and nitrogen sources, temperature, and different level of carbon and nitrogen sources (starch and tryptone).

\begin{tabular}{|c|c|c|c|c|c|c|c|c|c|c|c|c|c|}
\hline \multirow[b]{2}{*}{$\begin{array}{l}\text { Source of } \\
\text { variation }\end{array}$} & \multirow[b]{2}{*}{$\begin{array}{l}\text { Degrees of } \\
\text { freedom }\end{array}$} & \multicolumn{6}{|c|}{$\mathrm{pH}$} & \multicolumn{6}{|c|}{ Carbon Sources } \\
\hline & & 5 & 6 & 7 & 8 & 9 & - & Glucose & Starch & Lactose & Maltose & Fructose & - \\
\hline Replication & 2 & 0.002 & 0.42467 & 0.32067 & 0.9613 & 0.4687 & - & 0.26467 & 0.162 & 0.05067 & 0.2167 & 0.42467 & - \\
\hline \multirow[t]{3}{*}{ Residual error } & 8 & 0.032 & 0.733 & 0.35317 & 1.4853 & 0.2845 & - & 0.14967 & 0.14367 & 0.114 & 0.1525 & 0.2005 & - \\
\hline & & \multicolumn{6}{|c|}{ Nitrogen source } & \multicolumn{6}{|c|}{ Temperature $\left({ }^{\circ} \mathrm{C}\right)$} \\
\hline & $\begin{array}{l}\text { Degrees of } \\
\text { freedom }\end{array}$ & Glycine & Yeast extract & Tryptone & $\left(\mathrm{NH}_{4}\right)_{2} \mathrm{SO}_{4}$ & $\mathrm{NH}_{4} \mathrm{CL}$ & - & 25 & 28 & 30 & 35 & 37 & - \\
\hline Replication & 2 & 0.1147 & 0.14467 & 0.042 & 0.15267 & 0.66467 & - & 0.1647 & 0.3247 & 0.1167 & 0.126 & 0.2847 & - \\
\hline Treatment & 4 & $6.631^{* * *}$ & 0.34933 & 0.413 * & $0.676^{*}$ & $1.893 *$ & - & $20.464^{* * *}$ & $14.142^{* * *}$ & $8.259^{* * *}$ & $14.451^{* * *}$ & $3.424^{* *}$ & - \\
\hline \multirow[t]{3}{*}{ Residual error } & 8 & 0.1672 & 0.39883 & 0.08867 & 0.161 & 0.38217 & - & 0.2738 & 0.3163 & 0.0775 & 0.0677 & 0.3388 & - \\
\hline & & \multicolumn{6}{|c|}{ Starch concentration $(\%)$} & \multicolumn{6}{|c|}{ Tryptone concentration (\%) } \\
\hline & $\begin{array}{l}\text { Degrees of } \\
\text { freedom }\end{array}$ & 0.5 & 1 & 1.5 & 2 & 2.5 & 3 & 0.5 & 1 & 1.5 & 2 & 2.5 & 3 \\
\hline Replication & 2 & 0.0347 & 0.206 & 0.006 & 0.08867 & 0.0107 & 0.1607 & 0.0127 & 0.026 & 0.0507 & 0.1047 & 0.3227 & 0.1847 \\
\hline Treatment & 4 & $7.367^{* * *}$ & $5.353^{* * *}$ & $2.297^{* * *}$ & $1.922 * * *$ & $3.383^{* * *}$ & $7.034^{* *}$ & $9.837^{* * *}$ & $12.944^{* * *}$ & $12.612^{* * *}$ & $28.236^{* * *}$ & $10.561^{* * *}$ & $6.884^{* * *}$ \\
\hline
\end{tabular}

${ }^{*}=0.05$ significant variation. ${ }^{* *}=0.01$ significant variation. ${ }^{* * *}=0.001$ significant variation. 


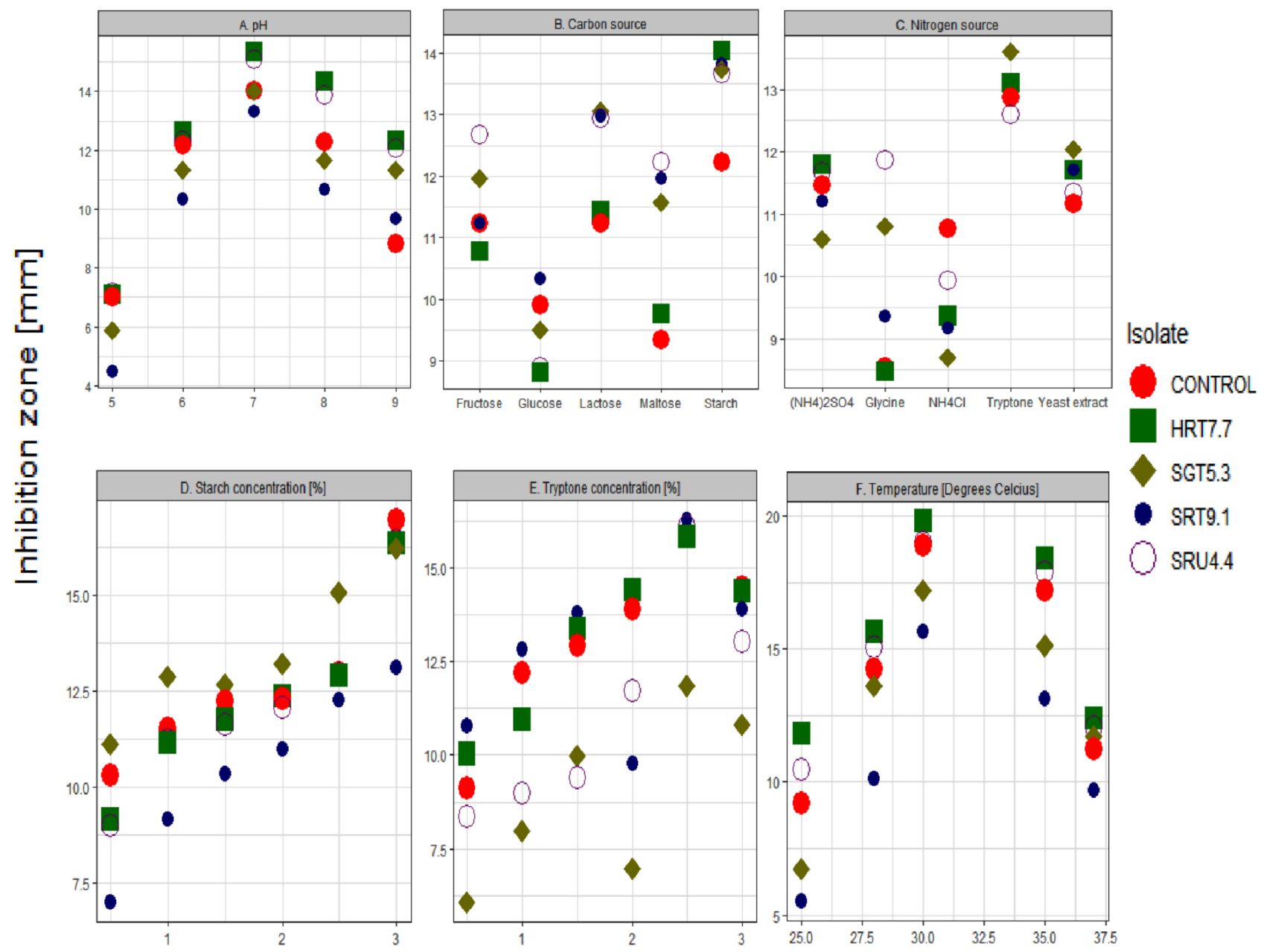

Figure 3. A scatter plot showing inhibition zones of the sweet pepper fruits isolates against the R. solanacearum BD 261 pathogenic strain, at different treatment levels of (A) $\mathrm{pH},(\mathbf{B})$ carbon sources, (C) nitrogen sources, (D) starch concentrations, (E) tryptone concentrations, and (F) temperature.

Although the nitrogen sources $\left(\mathrm{NH}_{4}\right)_{2} \mathrm{SO}_{4}$, yeast extract, and tryptone revealed an immense potential in the aiding activity of the antagonists against the pathogenic strain, $R$. solanacearum BD 261, tryptone was observed as the ideal nitrogen source (Figure 3C). Inhibitory zones of the isolates, together with the control, were all greater than $12.5 \mathrm{~mm}$ for the tryptone treatment and greater than those observed for the other nitrogen sources (Table S5). For this treatment, no meaningful differences in activity were detected between the isolates and the control (Table S6). However, as observed for tryptone, it is important to note that the activity of the isolates, under an environment enriched with tryptone, tended to be much higher at higher concentration levels (Figure 3E). Lastly, temperatures ranging from $27-35{ }^{\circ} \mathrm{C}$ were observed as ideal for promoting the activity of the antagonists against the pathogenic strain. However, the maximum activity was observed at a temperature of $30{ }^{\circ} \mathrm{C}$ (Figure 3F).

\subsection{Determination of Antimicrobial Traits of the Antagonists}

Bacillus cereus (HRT7.7), Paenibacillus polymyxa (SRT9.1), Serratia marcescens (SGT5.3), and Enterobacter hormaechei (SRU4.4) were evaluated for secondary metabolite production associated with antimicrobial activity, including cellulase and protease, on LB plates containing, CMC, and skim milk. Clear zones around the isolates exhibited their high cellulase and proteolytic activity (Figure 4a). Additionally, solubilization of insoluble 


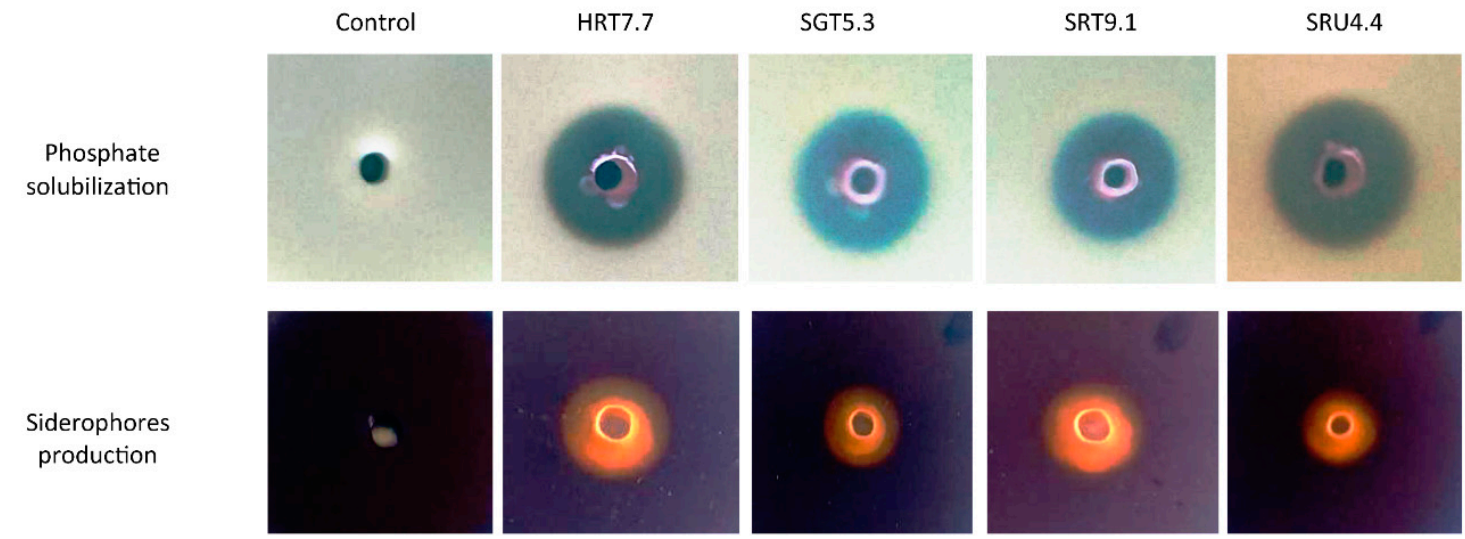

phosphate and siderophore production were also depicted by the clear zone halos around wells containing colonies and the yellow-orange halos formation around the CAS agar plates (Figure $4 \mathrm{~b}$ ). The assays clearly showed that the isolates potentially antagonize $R$. solanacearum using lytic enzymes and siderophore production, as well as by solubilizing phosphate, as their mode of action (Table S7).
Cellulase

Protease
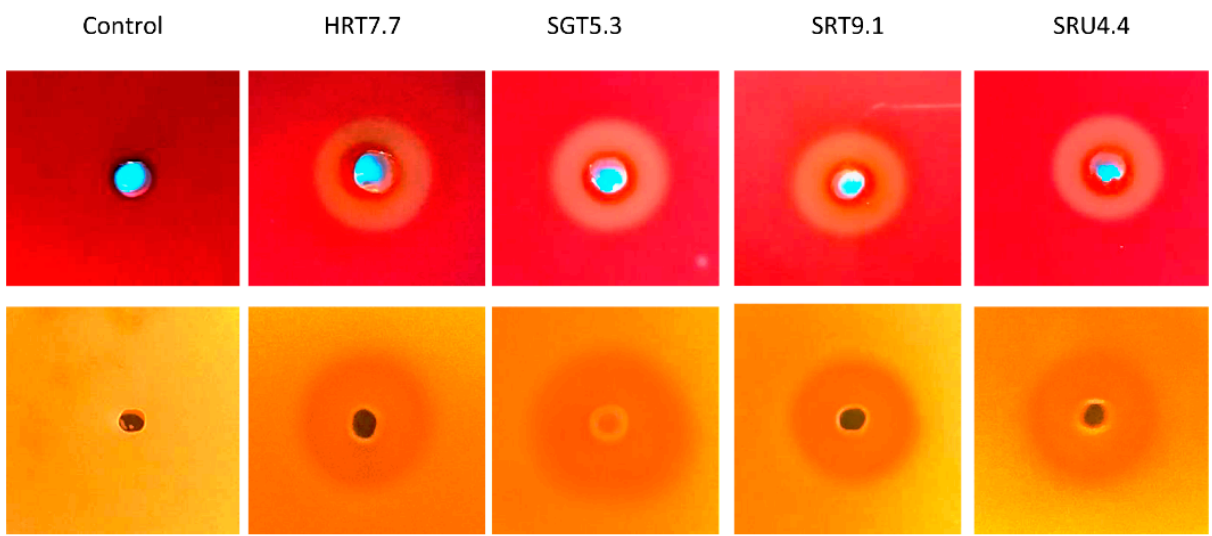

Figure 4. Production of antimicrobial traits by Bacillus cereus (HRT7.7), Paenibacillus polymyxa (SRT9.1), Serratia marcescens (SGT5.3), and Enterobacter hormaechei (SRU4.4). (a) Production of cellulase and protease, (b) phosphate solubilization, and siderophore production.

\section{Discussion}

Biological control (particularly, using antagonists) is poised as the most sustainable and environmentally safe, disease control strategy in crop production [22-24]. However, the roles of antagonists in controlling bacterial wilt, a disease caused by the most devastating and widely distributed pathogen of sweet peppers (i.e., $R$. solanacearum), are poorly understood. Here, potential bacterial antagonists were isolated from 80 red and green sweet pepper fruit samples, grown under hydroponic and open soil conditions, with some plants fungicide-treated while others were untreated. Amplicon sequencing of $16 \mathrm{~S}$ rDNA of the identified potential antagonists, together with microbial activity assays, showed the identities of the isolates as potential antagonists against $R$. solanacearum and revealed the optimal conditions of activity, as well as the mode of action of the isolates against the pathogenic strains.

Firstly, identification of the isolates Bacillus cereus strain HRT7.7, Paenibacillus polymyxa strain SRT9.1, Serratia marcescens strain SGT5.3, and Enterobacter hormaechei strain SRU4.4, as antagonists of $R$. solanacearum, was not surprising since several strains in the genera Bacillus, Enterobacter, Serratia, and Paenibacillus were previously reported to suppress R. solanacearum in vitro [46]. The ability of these strains to inhibit the growth of phytopathogenic bacteria, as observed in this study, places them as suitable biocontrol agents in crop production. 
Different studies have demonstrated that temperature is one of the significant factors that influence microbial antagonist growth and activity $[47,48]$. Our results also demonstrated temperature as an essential parameter in determining the antagonistic activity of bacterial antagonists against $R$. solanacearum BD 261. Although temperatures that range between $27-35{ }^{\circ} \mathrm{C}$ were ideal for the antagonistic activity, $30{ }^{\circ} \mathrm{C}$ was optimal. This finding has several implications for decision-making in crop production. For instance, since the antagonists prefer on average high temperatures for maximum activity, this suggests that application of the bacteria as a biological control measure on the crop should be made in the afternoon when temperatures are high. However, for horticultural crops such as sweet peppers, which are predominantly grown under controlled environments (e.g., greenhouses), after applying these antagonists, it would be good to maintain temperatures at $30^{\circ} \mathrm{C}$ (i.e., the optimal temperature), in order to encourage maximum suppression of the pathogen. These high temperatures will not affect the sweet pepper plants physiologically since the plants are thermophilic in nature [1].

As in agreement with [49], the present results exhibited the antagonistic activity against $R$. solanacearum over a wide $\mathrm{pH}$ range (Figure $3 \mathrm{~A}$ ), with the maximum antimicrobial activity at $\mathrm{pH}$ 7. At an optimal $\mathrm{pH}$ level, cell growth and enzyme production (e.g., lytic enzymes) occur [49]. Several previous studies reported that near-neutral $\mathrm{pH}$ is appropriate for most bacteria to synthesize antagonistic substances [50].

Apart from supporting microbial growth, the amendment of the medium with carbon and nitrogen sources is known to strongly influence antimicrobial activity and synthesis of antimicrobial metabolites by microbial strains [51]. The present study depicted that carbon and nitrogen sources (particularly, high concentration of starch and tryptone) in the growth medium play an important role in encouraging antagonistic activity against $R$. solanacearum BD 261 (Figure 3). Interestingly, these results strongly agreed with previous studies, in which antimicrobial activity of B. cereus [52], E. hormaechei [53], P. polymyxa [54], and $S$. marcescens [55] were shown to be strongly influenced by the medium with carbon and nitrogen sources. These findings could as well help agro-chemical companies that will be interested in packaging these potential antagonists as bio-control pesticides. For instance, in formulations, antagonistic bacteria can be mixed with the most important carbon and nitrogen sources identified in this study (i.e., starch and tryptone), as this will improve the efficacy of these bio-pesticides against the $R$. solanacearum BD 261 pathogen.

Previous studies by [51,56] reported that several antagonistic bacteria (e.g., Bacillus spp., Paenibacillus spp., Serratia spp. and other Enterobacter spp.) secrete lytic enzymes including amylase, cellulases, and chitinases, which are capable of degrading chitin. The secretion of these enzymes is considered as the major and the most effective antagonistic mode of action deployed by various bacteria against plant phytopathogens [57]. Apart from suppressing pathogenic microbes, antagonists also indirectly promote plant growth and development through organic matter decomposition, phosphate solubilization, and siderophore production [58]. The present results corroborate these previous accessions, as siderophores and phosphate solubilization potential was also shown (Figure 4b). In addition, cellulase and protease activity depicted by the isolates against $R$. solanacearum was also reported in previous studies $[59,60]$. To the best of our knowledge, this is the first report of the isolation of a comprehensive range of epiphytic bacteria with antagonistic potential, from the surface of a fruit crop.

\section{Conclusions}

In conclusion, we have successfully isolated effective antagonistic strains from the surfaces of fresh red and green sweet pepper fruits viz. Bacillus cereus strain HRT7.7, Paenibacillus polymyxa strain SRT9.1, Serratia marcescens strain SGT5.3, and Enterobacter hormaechei strain SRU4.4. These strains exhibited a strong antagonistic activity for suppressing $R$. solanacearum in vitro, by secreting lytic enzymes such as cellulase and protease. The strains further exhibited the capability of solubilizing phosphate and siderophores production, making them good candidates as biocontrol and noble plant growth-promoting 
(PGP) agents. As in vitro studies should be considered before the commencement of any green house and field studies, the present study delivers a piece of convincing evidence that surface fresh pepper fruits (especially, from plants grown under open soil environments) harbor bacteria with the ability to offer plant protection against phytopathogens. Future investigation of these beneficial strains will involve the analysis of the expression of defense-related genes such as phenylalanine ammonia lyase in pepper plants and an evaluation of their ability to control $R$. solanacearum BD 261 and other pathogens in vivo, under different environmental conditions and cultural practices. In order to understand the pathways and mechanisms of suppressing the pathogen, further studies will encompass analyzing antagonist strains whole-genome sequencing. Additionally, in the future, the establishment of the relationship between metabolite or antioxidant production by the sweet pepper fruits treated with these antagonistic strains and the level (i.e., growth and antibacterial activity) will be of paramount importance since all plants deploy inherent mechanisms to resist or tolerate both the abiotic and biotic stresses.

Supplementary Materials: The following are available online at https:/ / www.mdpi.com/article / 10.3390/microorganisms9091947/s1, Figure S1: Antagonistic activity of HRT7.7, SGT5.3, SRT9.1, SRU4.4 and Bacillus stratosphericus (LT743897) positive control against Ralstonia solanacearum pathogen, Figure S2: Agarose gel electrophoresis analysis of 16S rRNA genes amplified from four unknown bacterial isolates using primers 27F/1492R. PCR amplified products were run on $1 \%$ agarose gel. Lane M contains the DNA Ladder (NEB Fast DNA Ladder Mix 0.5 kb-10 kb, catalogue number N3238S), lane 1: HRT7.7, lane 2: SGT5.3, lane 3: SRT9.1, lane 4: SRU4.4. Table S1: The 800 morphologically distinct colonies isolated from the 80 green and red sweet pepper fruit samples grown under hydroponic and open soil conditions (fungicide-treated and untreated) at the ARCVegetables and Ornamental Center in South Africa, during the 2014-2015 autumn and summer season (supplied as an excel sheet), where negative means incapable of suppressing the pathogen and positive means capable of suppressing the pathogen. Table S2: Analysis of variance (ANOVA) for bacterial colonies with potential antagonistic effects, isolated from sweet pepper fruit surfaces, against the R. solanacearum BD 261 pathogenic strain, before and after enrichment. Table S3: Antagonistic potential of bacterial isolates from green and red sweet pepper fruit samples, grown under hydroponic and open soil conditions (but, either fungicide-treated or untreated) at the ARC-VOC, during the 2014-2015 autumn and summer season in South Africa, against the R. solanacearum BD 261 strain, before and after enrichment. Table S4: Turkey's HSD mean comparisons of the bacterial isolates from green and red sweet pepper fruit samples, grown under hydroponic and open soil conditions (but, either fungicide-treated or untreated) at the ARC-VOC, during the 2014-2015 autumn and summer season in South Africa, against the R. solanacearum BD 261 strain, before and after enrichment. Table S5: Antagonistic activity of sweet pepper fruit isolates, against the R. solanacearum BD 261 strain, at different treatment levels of $\mathrm{pH}$, carbon sources and nitrogen sources, temperature, starch and tryptone. Table S6: Turkey's HSD mean comparisons of antagonistic activity of the sweet pepper fruit isolates, against the R. solanacearum BD 261 strain, at different treatment levels of $\mathrm{pH}$, carbon sources and nitrogen sources, temperature, different level of carbon and nitrogen sources (starch and tryptone) (supplied as an excel sheet). Table S7: Specific modes of action by antagonistic bacteria against R. solanacearum BD 261.

Author Contributions: Conceptualization, T.P.M., M.M.M., O.A.A. and O.O.B.; investigation, T.P.M.; methodology, T.P.M. and O.A.A.; formal analysis, T.P.M. and C.N.K.; resources, M.M.M., O.A.A. and O.O.B.; data curation, T.P.M., O.A.A. and O.O.B.; writing-original draft preparation, T.P.M.; writing-review and editing, C.N.K., M.M.M., O.A.A. and O.O.B.; supervision, O.A.A. and O.O.B.; project administration, O.A.A.; funding acquisition, O.A.A. All authors have read and agreed to the published version of the manuscript.

Funding: This research was funded by Agricultural Research Council and the National Research Foundation, South Africa according to the research project number PO2000032.

Institutional Review Board Statement: Not applicable.

Informed Consent Statement: Not applicable. 
Data Availability Statement: The partial sequenced data (16S rRNA region) is available at the GenBank database with accession number, MN911398.1-MN911401.1. (https:/ / www.ncbi.nlm.nih.gov/ nuccore/MN911398.1; https:/ / www.ncbi.nlm.nih.gov/nuccore/MN911401.1; https:/ /www.ncbi. nlm.nih.gov/nuccore/MN911399.1; https:/ / www.ncbi.nlm.nih.gov/nuccore/MN911400.1; accessed on 9 January 2020).

Acknowledgments: The authors would like to thank Phathutshedzo Ramudingana for assistance in sampling, and Teresa Goszczynska for providing R. solanacearum BD 261 pathogenic strain. The authors are also grateful to the North-West University, for the research collaboration platform. The authors would also like to thank Mark Paul Taylor for proofreading the manuscript.

Conflicts of Interest: The authors declare no conflict of interest.

\section{References}

1. FAOSTAT. Food and Agricultural Commodities Production. 2014. Available online: http://faostat.fao.org (accessed on 22 February 2017).

2. Govender, L.; Pillay, K.; Siwela, M.; Modi, A.; Mabhaudhi, T. Food and nutrition insecurity in selected rural communities of KwaZulu-Natal, South Africa-Linking human nutrition and agriculture. Int. J. Environ. Res. Public Health 2016, 14, 17. [CrossRef] [PubMed]

3. Kairiza, T.; Kembo, G.D. Coping with food and nutrition insecurity in Zimbabwe: Does household head gender matter? Agric. Food Econ. 2019, 7, 1-16. [CrossRef]

4. Serpeloni, J.M.; Specian, A.F.; Ribeiro, D.L.; Tuttis, K.; Vilegas, W.; Martínez-López, W.; Dokkedal, A.L.; Saldanha, L.L.; Cólus, I.M.; Varanda, E.A. Antimutagenicity and induction of antioxidant defense by flavonoid rich extract of Myrcia bella Cambess. in normal and tumor gastric cells. J. Ethnopharmacol. 2015, 176, 345-355. [CrossRef] [PubMed]

5. Shahidi, F.; Ambigaipalan, P. Phenolics and polyphenolics in foods, beverages and spices: Antioxidant activity and health effects-A review. J. Funct. Foods 2015, 18, 820-897. [CrossRef]

6. Deepa, N.; Kaur, C.; George, B.; Sing, B.; Kapoor, H.C. Antioxidant constituents in some sweet pepper (Capsicum annuum L.) genotypes during maturity. LWT Food Sci. Technol. 2017, 40, 121-129. [CrossRef]

7. Chen, L.; Kang, Y.-H. Anti-inflammatory and antioxidant activities of red pepper (Capsicum annuum L.) stalk extracts: Comparison of pericarp and placenta extracts. J. Funct. Foods 2013, 5, 1724-1731. [CrossRef]

8. Sreeramulu, D.; Raghunath, M. Antioxidant activity and phenolic content of roots, tubers and vegetables commonly consumed in India. Food Res. Int. 2010, 43, 1017-1020. [CrossRef]

9. Luning, P.A.; Vries, R.V.D.V.D.; Yuksel, D.; Ebbenhorst-Seller, T.; Wichers, H.; Roozen, J.P. Combined instrumental and sensory evaluation of flavor of fresh bell peppers (Capsicum annuum) harvested at three maturation stages. J. Agric. Food Chem. 1994, 42, 2855-2861. [CrossRef]

10. Tundis, R.; Menichini, F.; Bonesi, M.; Conforti, F.; Statti, G.; Menichini, F.; Loizzo, M.R. Antioxidant and hypoglycaemic activities and their relationship to phytochemicals in Capsicum annuum cultivars during fruit development. LWT Food Sci. Technol. 2013, 53, 370-377. [CrossRef]

11. López, A.; Fenoll, J.; Hellín, P.; Flores, P. Cultivation approach for comparing the nutritional quality of two pepper cultivars grown under different agricultural regimes. LWT Food Sci. Technol. 2014, 58, 299-305. [CrossRef]

12. Pagán, I.; García-Arenal, F. Tolerance to plant pathogens: Theory and experimental evidence. Int. J. Mol. Sci. 2018, 19, 810. [CrossRef]

13. Kover, P.X.; Schaal, B.A. Genetic variation for disease resistance and tolerance among Arabidopsis thaliana accessions. Proc. Natl. Acad. Sci. USA 2002, 99, 11270-11274. [CrossRef] [PubMed]

14. Cernava, T.; Müller, H.; Aschenbrenner, I.A.; Grube, M.; Berg, G. Analyzing the antagonistic potential of the lichen microbiome against pathogens by bridging metagenomic with culture studies. Front. Microbiol. 2015, 6, 620. [CrossRef] [PubMed]

15. Dang, Z.; McLenachan, P.A.; Lockhart, P.J.; Waipara, N.; Er, O.; Reynolds, C.; Blanchon, D. Metagenome profiling identifies potential biocontrol agents for Selaginella kraussiana in New Zealand. Genes 2019, 10, 106. [CrossRef] [PubMed]

16. Mansfield, J.; Genin, S.; Magori, S.; Citovsky, V.; Sriariyanum, M.; Ronald, P.; Dow, M.; Verdier, V.; Beer, S.V.; Machado, M.A.; et al. Top 10 plant pathogenic bacteria in molecular plant pathology. Mol. Plant Pathol. 2012, 13, 614-629. [CrossRef]

17. Knapp, S.; Bohs, L.; Nee, M.; Spooner, D.M. Solanaceae-A model for linking genomics with biodiversity. Comp. Funct. Genomics 2004, 5, 285-291. [CrossRef]

18. Swanson, J.K.; Yao, J.; Tans-Kersten, J.; Allen, C. Behavior of Ralstonia solanacearum Race 3 Biovar 2 during latent and active infection of geranium. Phytopathology 2005, 95, 136-143. [CrossRef]

19. Kelman, A. One hundred and one years of research on bacterial wilt. In Bacterial Wilt: Molecular and Ecological Aspects; Prior, P., Allen, C., Eds.; Springer: Berlin, Germany, 1998; pp. 1-5.

20. Nion, Y.A.; Toyota, K. Recent trends in control methods for bacterial wilt diseases caused by Ralstonia solanacearum. Microbes Environ. 2015, 30, 1-11.

21. Bannihatti, R.K.; Suryawanshi, A.P. Integrated management of bacterial wilt of tomato caused by Ralstonia solanacearum. Int. J. Chem. Stud. 2019, 7, 1599-1603. 
22. Kamal, R.; Gusan, Y.S.; Kumar, V.; Sharma, A. Disease management through biological control agents: An eco-friendly and cost effective approach for sustainable agriculture-A Review. Agric. Rev. 2015, 36, 37-45. [CrossRef]

23. Sharma, M.; Tarafdar, A.; Ghosh, R.; Gopalakrishanan, S. Biological control as a tool for eco-friendly management of plant pathogens. In Advances in Soil Microbiology: Recent Trends and Future Prospects; Adhya, T., Mishra, B., Annapurna, K., Verma, D., Kumar, U., Eds.; Springer: Singapore, 2017; pp. 153-188.

24. Mamphogoro, T.P.; Babalola, O.O.; Aiyegoro, O.A. Sustainable management strategies for bacterial wilt of sweet peppers (Capsicum annuum) and other Solanaceous crops. J. Appl. Microbiol. 2020, 129, 496-508. [CrossRef]

25. Yuan, S.; Wang, L.; Wu, K.; Shi, J.; Wang, M.; Yang, X.; Shen, Q.; Shen, B. Evaluation of Bacillus-fortified organic fertilizer for controlling tobacco bacterial wilt in greenhouse and field experiments. Appl. Soil Ecol. 2013, 75, 86-94. [CrossRef]

26. Wei, Z.; Huang, J.; Tan, S.; Mei, X.; Shen, Q.; Xu, Y. The congeneric strain Ralstonia pickettii QL-A6 of Ralstonia solanacearum as an effective biocontrol agent for bacterial wilt of tomato. Biol. Control 2013, 65, 278-285. [CrossRef]

27. Durairaj, K.; Velmurugan, P.; Park, J.H.; Chang, W.S.; Park, Y.J.; Senthilkumar, P.; Choi, K.M.; Lee, J.H.; Oh, B.T. Potential for plant biocontrol activity of isolated Pseudomonas aeruginosa and Bacillus stratosphericus strains against bacterial pathogens acting through both induced plant resistance and direct antagonism. FEMS Microbiol. Lett. 2017, 364, fnx225. [CrossRef] [PubMed]

28. Mamphogoro, T.P.; Maboko, M.M.; Babalola, O.O.; Aiyegoro, O.A. Bacterial communities associated with the surface of fresh sweet pepper (Capsicum annuum) and their potential as biocontrol. Sci. Rep. 2020, 10, 8560. [CrossRef]

29. Paulino, L.C.; Tseng, C.H.; Strober, B.E.; Blaser, M.J. Molecular analysis of fungal microbiota in samples from healthy human skin and psoriatic lesions. J. Clin. Microbiol. 2006, 44, 2933-2941. [CrossRef]

30. Shutt, V.; Shin, G.; Van Der Waals, J.; Goszczynska, T.; Coutinho, T. Characterization of Ralstonia strains infecting tomato plants in South Africa. Crop Prot. 2018, 112, 56-62. [CrossRef]

31. Facelli, E.; Taylor, C.; Scott, E.; Fegan, M.; Huys, G.; Noble, R.D.; Swings, J.; Sedgley, M. Identification of the causal agent of pistachio dieback in Australia. Eur. J. Plant Pathol. 2005, 112, 155-165. [CrossRef]

32. Nguyen, M.T.; Ranamukhaarachchi, S.L. Soil-borne antagonists for biological control of bacterial wilt disease caused by Ralstonia solanacearum in tomato and pepper. J. Plant Pathol. 2010, 92, 395-406.

33. Doan, T.T.; Nguyen, T.H.; Zeller, H.; Ullrich, C. Status of research on biological control of tomato and groundnut bacterial wilt in Vietnam. In Proceedings of the 1st International Symposium Biological Control of Bacterial Plant Diseases, Seeheim/Darmstadt, Germany, 23-26 October 2005; Zeller, W., Ullrich, C., Eds.; Federal Biological Research Center for Agriculture and Forestry: Berlin, Germany, 2006; pp. 105-111.

34. Arturo, A.M.; Oldelson, D.A.; Hichey, R.F.; Tiedje, J.M. Bacterial community fingerprinting of amplified 16-23S ribosomal DNA gene and restriction endonuclease analysis. In Molecular Microbial Ecology Manual; Akkermans, A.D.L., van Elsas, J.D., Bruijn, F.J., Eds.; Springer: Dordrecht, the Netherlands, 1995; pp. 1-8.

35. Turner, S.; Pryer, K.M.; Miao, V.P.; Palmer, J.D. Investigating deep phylogenetic relationships among cyanobacteria and plas-tids by small subunit rRNA sequence analysis. J. Eukaryot. Microbiol. 1999, 46, 327-338. [CrossRef]

36. Altschul, S.F.; Madden, T.L.; Schäffer, A.A.; Zhang, J.; Zhang, Z.; Miller, W.; Lipman, D.J. Gapped BLAST and PSI-BLAST: A new generation of protein database search programs. Nucleic Acids Res. 1997, 25, 3389-3402. [CrossRef]

37. Tamura, K.; Stecher, G.; Peterson, D.; Filipski, A.; Kumar, S. MEGA6: Molecular evolutionary genetics analysis version 6.0. Mol. Biol. Evol. 2013, 30, 2725-2729. [CrossRef] [PubMed]

38. Saitou, N.; Nei, M. The neighborjoining method: A new method for reconstructing phylogenetic trees. Mol. Biol. Evol. 1987, 4, 406-425.

39. Costa, E.; Teixidó, N.; Usall, J.; Atarés, E.; Vinas, I. The effect of nitrogen and carbon sources on growth of the biocontrol agent Pantoea agglomerans strain CPA-2. Lett. Appl. Microbiol. 2002, 35, 117-120. [CrossRef] [PubMed]

40. Teather, R.M.; Wood, P.J. Use of Congo red-polysaccharide interactions in enumeration and characterization of cellulolytic bacteria from the bovine rumen. Appl. Environ. Microbiol. 1982, 43, 777-780. [CrossRef] [PubMed]

41. Sokol, P.A.; Ohman, D.E.; Iglewski, B.H. A more sensitive plate assay for detection of protease production by Pseudomanas aeruginosa. J. Clin. Microbiol. 1979, 9, 538-540. [CrossRef] [PubMed]

42. Nautiyal, C.S. An efficient microbiological growth medium for screening phosphate-solubilizing microorganisms. FEMS Microbiol. Lett. 1999, 170, 265-270. [CrossRef]

43. Schwyn, B.; Neilands, J.B. Universal CAS assay for the detection and determination of siderophores. Anal. Biochem. 1987, 160, 47-56. [CrossRef]

44. Mendiburu, F.; Simon, R. Agricolae - Ten years of an open source statistical tool for experiments in breeding, agriculture and biology. Peer J. PrePrints 2015, 3, e1404v1.

45. Wickham, H.; Dianne, C.; Heike, H. Visualizing statistical models: Removing the blindfold. Stat. Anal. Data Min. 2015, 8, 203-225. [CrossRef]

46. Long, H.H.; Furuya, N.; Kurose, D.; Takeshita, M.; Takanami, Y. Isolation of endophyiic bacteria from Solawam sp. and their antibacterial activity against plant pathogenic bacteria. J. Fac. Agric. Kyushu Univ. 2003, 48, 21-28. [CrossRef]

47. Lee, H.B.; Magan, N. Environmental factors and nutritional utilization patterns affect niche overlap indices between Aspergillus ochraceus and other spoilage fungi. Lett. Appl. Microbiol. 1999, 28, 300-304. [CrossRef] [PubMed]

48. Kok, C.J.; Papert, A. Effect of temperature on in vitro interactions between Verticillium chlamydosporium and other Meloidogyneassociated microorganisms. BioControl 2002, 47, 603-606. [CrossRef] 
49. Passari, A.K.; Mishra, V.K.; Leo, V.V.; Gupta, V.K.; Singh, B.P. Phytohormone production endowed with antagonistic potential and plant growth promoting abilities of culturable endophytic bacteria isolated from Clerodendrum colebrookianum Walp. Microbiol. Res. 2016, 193, 57-73. [CrossRef]

50. Kim, Y.S.; Balaraju, K.; Jeon, Y.H. Biological characteristics of Bacillus amyloliquefaciens AK-0 and suppression of ginseng root rot caused by Cylindrocarpon destructans. J. Appl. Microbiol. 2017, 122, 166-179. [CrossRef] [PubMed]

51. El-Sayed, W.S.; Akhkha, A.; El-Naggar, M.Y.; Elbadry, M. In vitro antagonistic activity, plant growth promoting traits and phylogenetic affiliation of rhizobacteria associated with wild plants grown in arid soil. Front. Microbiol. 2014, 5, 651. [CrossRef]

52. Avc1, A.; Çağr1-Mehmetoğlu, A.; Arslan, D. Production of antimicrobial substances by a novel Bacillus strain inhibiting Salmonella typhimurium. LWT-Food Sci. Technol. 2017, 80, 265-270. [CrossRef]

53. Nutaratat, P.; Monprasit, A.; Srisuk, N. High-yield production of indole-3-acetic acid by Enterobacter sp. DMKU-RP206, a rice phyllosphere bacterium that possesses plant growth-promoting traits. 3 Biotech 2017, 7, 305. [CrossRef]

54. Raza, W.; Yang, W.; Shen, Q. Paenibacillus polymyxa: Antibiotics, hydrolytic enzymes and hazard assessment. J. Plant. Pathol. 2008, 90, 419-430.

55. Lin, C.; Jia, X.; Fang, Y.; Chen, L.; Zhang, H.; Lin, R.; Chen, J. Enhanced production of prodigiosin by Serratia marcescens FZSF02 in the form of pigment pellets. Electron. J. Biotechnol. 2019, 40, 58-64. [CrossRef]

56. Dhar Purkayastha, G.; Mangar, P.; Saha, A.; Saha, D. Evaluation of the biocontrol efficacy of a Serratia marcescens strain indigenous to tea rhizosphere for the management of root rot disease in tea. PLoS ONE 2018, 13, e0191761. [CrossRef] [PubMed]

57. Xu, S.J.; Hong, S.J.; Choi, W.; Kim, B.S. Antifungal activity of Paenibacillus kribbensis strain T-9 isolated from soils against several plant pathogenic fungi. Plant Pathol. J. 2014, 30, 102-108. [CrossRef] [PubMed]

58. Han, J.-H.; Shim, H.; Shin, J.H.; Kim, K.S. Antagonistic activities of bacillus spp. strains isolated from tidal flat sediment towards anthracnose pathogens Colletotrichum acutatum and C. gloeosporioides in South Korea. Plant Pathol. J. 2015, 31, 165-175. [CrossRef] [PubMed]

59. Compant, S.; Duffy, B.; Nowak, J.; Clément, C.; Barka, E.A. Use of plant growth-promoting bacteria for biocontrol of plant diseases: Principles, mechanisms of action, and future prospects. Appl. Environ. Microbiol. 2005, 71, 4951-4959. [CrossRef]

60. Nelson, L.M. Plant growth promoting rhizobacteria (PGPR): Prospects for new inoculants. Crop Manag. 2004, 3, 1-7. [CrossRef] 